\title{
COREFSPONDEINCE.
}

\section{DEEP-BORING IN PRUSSIA, ETC.}

SIr,-It may interest some of the readers of the Geologicax Magazine to learn that a boring has lately been carried out by the German Government at Sperenberg, twenty-five miles south of Berlin, which has reached the surprising depth of 4040 feet! and is the deepest boring in the world (not even excepting America)! It is almost all through the Saliferous Rocks, Triassic series (Keuper, Muschelkalk, and Bunter), and was finished in 1872. The boring is done with rods, but the details I have not yet learned.

The following Extract from a letter, 19th Nov., 1874, from Thos. J. Bewick, Civil and Mining Engineer, to Major Beaumont, M.P., Managing Director, Diamond Rock-Boring Company, Limited, 2, Westminster Chambers, London, may prove of interest, as showing what can be done by means of Diamond Boring.

"Bohemian Broad-Bore-HoLe.

"Actual boring was commenced on the 15th July last. On 8th inst. the depth was 1931 Vienna feet, equal $20014^{\prime \prime}$ English feet. At commencement bored 35 feet, when stopped by fall of ground. $13^{\prime}$ more, equal to $48^{\prime}$, lined with 5 inch tubes, and then bored up to 96 feet with 4 inch crown. Lost water by a cleft at 73 feet. Bored to 180 feet with 4 inch crown. Again lost water from tubes not being close to the bottom. Withdrew 96 feet of tubes, and widened the whole to 180 feet with 5 inch crown. Lined with 5 inch tubes to that depth, and continued with 3 inch crown to bottom. No more tubes required after 180 feet. Usual recent rate of boring 30 to 40 feet per day of 24 hours ( 2 shifts of 12 hours each). Boring is in New Red Sandstone formation. Conglomerate occurred from 520 to 580 feet, 680 to 850 feet, and 1200 to 1510 feet, equal to 540 feet in all. The pebbles were firm, with but few loose stones. The Conglomerate consists of porphyry, Silurian shales, granite, and quartz. The rest of the strata are the usual Sandstones, Shales, and Marls in the New Red Sandstone formation."

I can only hope the Sub-Wealden Exploration may succeed in attaining as great a depth as that of Sperenberg, near Berlin.--J. P.

ENGLAND AND FRANCE IN THE GLACTAL EPOCH.

SrR,-In a clever and able article by Mr. Thomas Belt, F.G.S., published in the "Quarterly Journal of Science" for October last, that gentleman advocates the theory of a great river flowing southwards, towards the close of the Glacial epoch, down what is now the English Channel, and embracing the Rhine, the Thames, the Seine, and other rivers in its course.

This is, I believe, contrary to the generally received notion that the Straits of Dover had not then been cut, and that the Thames flowed northwards to join the Rhine.

Perhaps Professor Prestwich or some other of your Quaternary Geological readers will relieve my mind by telling me which is the right faith.

J. Sussux. 